\title{
The association between maternal hepatitis $B$ e antigen status, as a proxy for perinatal transmission, and the risk of hepatitis B e antigenaemia in Gambian children
}

Yusuke Shimakawa ${ }^{1,2^{*}}$, Christian Bottomley ${ }^{2}$, Ramou Njie ${ }^{1,3}$ and Maimuna Mendy ${ }^{4}$

\begin{abstract}
Background: Early age at infection with hepatitis B virus (HBV) increases the risk of chronic HBV infection. In addition early age at infection may further increase the risk of persistent viral replication beyond its effect on chronicity. The effects of perinatal and early postnatal transmission on the risk of prolonged hepatitis B e antigenaemia in children with chronic HBV infection are not well documented in Africa. We examine these associations using maternal HBV sero-status and the number of HBV-positive older siblings as proxy measures for perinatal and early postnatal transmission, respectively.

Methods: Hepatitis B e antigen (HBeAg)-positive mothers were identified in six population-based HBV sero-surveys conducted in The Gambia between 1986 and 1990. For every HBeAg-positive mother, a hepatitis B surface antigen ( $\mathrm{HBsAg}$ )-positive $\mathrm{HBeAg}$-negative mother and $\mathrm{HBsAg}$-negative mother were randomly selected from the population surveyed. These mothers and their family members were tested for HBV sero-markers in a subsequent survey conducted between 1991 and 1993.

Results: Thirty-eight HBeAg positive mothers and the same number of HBsAg-positive HBeAg-negative mothers and HBsAg-negative mothers participated in the study. Sixty-nine percent of their children also participated. There was a non-significant positive association between HBeAg prevalence in children and the number of HBeAg-positive older siblings (64.1\%,69.2\% and 83.3\% in children with 0,1 and $\geq 2$ HBeAg-positive older siblings, respectively). After adjusting for confounders, having an HBeAg-positive mother was a risk factor for HBeAg positivity in children carrying $\mathrm{HBsAg}$ (adjusted OR 4.5, 95\% Cl: 1.0-19.5, $\mathrm{p}=0.04$ ), whilst the number of HBeAg-positive older siblings was not.
\end{abstract}

Conclusions: Maternal HBeAg was associated with positive HBeAg in children with chronic HBV infection. This suggests that interrupting mother-to-infant transmission in sub-Saharan Africa might help reduce the burden of liver disease. A timely dose of HBV vaccine within 24 hours of birth, as recommended by WHO, should be implemented in sub-Saharan Africa.

Keywords: Hepatitis B, Hepatitis B e antigens, Infectious disease transmission, Vertical, Age factors, Africa

\footnotetext{
*Correspondence: yshimakawa@mrc.gm

'Medical Research Council (MRC) Unit, Atlantic Boulevard, Fajara, P.O. Box

273, Banjul, The Gambia

${ }^{2}$ Department of Infectious Disease Epidemiology, London School of Hygiene and Tropical Medicine, Keppel Street, London WC1E 7HT, UK

Full list of author information is available at the end of the article
} 


\section{Background}

Chronic infection with the hepatitis B virus (HBV) is a cause of hepatocellular carcinoma (HCC) [1]. The risk of chronic infection after exposure to HBV depends on the age at infection; infection becomes chronic in 80-90\%, $20-30 \%,<10 \%$, and $<5 \%$ of individuals who are infected during perinatal period, early childhood, adolescence and adulthood, respectively [2]. Early HBV infection is therefore associated with a higher risk of HCC through the increased risk of chronic infection [3]. However, beyond its effect of increasing the chance of becoming a chronic carrier, early age at HBV infection may further increase the risk of persistent viral replication, which ultimately leads to HCC [4]. The immaturity of the host immune system in neonates and toddlers has been suggested as a mechanism of prolonged e antigenaemia [5].

A recent systematic review of observational studies [6] found a positive association between having a mother positive for HBV sero-marker (a proxy for perinatal mother-to-infant transmission) and prolonged hepatitis $\mathrm{B}$ e antigenaemia (an indicator of high viral replication) amongst children with chronic HBV infection. There was also a positive association between maternal seropositivity and paediatric HCC. These findings suggest that $\mathrm{HBV}$ infection in early life through perinatal maternal transmission might increase the risk of $\mathrm{HCC}$ by maintaining a high viral replication.

However, the scope of the review was limited since: 1 ) most of the studies included were from East Asia where mother-to-infant transmission is frequent [7], and 2) none of the studies examined the infectious status of older siblings, who are known to be a major source of HBV infection in many parts of the world including sub-Saharan Africa (sSA) $[5,8,9]$. Thus, the contribution of siblingto-sibling HBV transmission during early childhood to the prolonged viral replication remains to be determined.

In this study we examined the association between age at $\mathrm{HBV}$ infection and the presence of hepatitis $\mathrm{B}$ e antigen (HBeAg) in The Gambia, West Africa, using maternal HBV sero-status and number of HBV-positive older siblings as a proxy for perinatal and early postnatal transmission, respectively. The analysis was restricted to study participants with positive hepatitis B surface antigen (HBsAg), because our aim was to identify the effect of age at infection (or mode of transmission) on the risk of hepatitis $\mathrm{B}$ e antigenaemia, beyond its effect of increasing the risk of chronic HBV infection [6].

\section{Methods}

\section{Setting}

A nation-wide hepatitis B vaccination trial was initiated in The Gambia in 1986 and by 1990 countrywide coverage was achieved [10]. In parallel, six population-based sero-surveys for $\mathrm{HBV}$ infection were conducted in The
Gambia between 1986 and 1990 to assess immunological response to the vaccine and to determine risk factors for HBV transmission [9-11]. These surveys obtained sera from both children and their mothers and tested for the presence of HBsAg in all the samples, and those that tested positive for HBsAg were further tested for HBeAg. In total, $53 \mathrm{HBeAg-positive} \mathrm{mothers} \mathrm{were} \mathrm{identified}$ from these studies (Figure 1).

On the basis of the HBV sero-status determined at these surveys, all HBeAg-positive mothers were invited to participate in "HBeAg Study". The same numbers of HBsAg-positive HBeAg-negative mothers and HBsAgnegative mothers were randomly selected from the databases used in these surveys. Between 1991 and 1993, these mothers (i.e., index women) and their family members were bled for HBV markers to determine the effect of familial HBV sero-markers on presence of HBeAg.

After consent was obtained, the index women were bled and interviewed to collect demographic information on dead and living family members. Index women were bled twice, the first bleeding occurred between 1986 and 1990 and the second at the time of the HBeAg Study (1991-1993). We used the serological status recorded in the first survey as a proxy for serological status at birth of their children.

Family members of the index woman (excluding half siblings), were contacted and if they agreed to participate in the study, were bled for HBV serology. All sera were assayed for $\mathrm{HBsAg}$ by reverse passive haemagglutination (Wellcotest, Murex Diagnostics, UK). HBeAg was tested by radioimmunoassay (Sorin, Biomedica, Italy) only when sera were HBsAg-positive. The study was approved by the Gambia Government/MRC (Medical Research Council) Joint Ethical Committee and the ethics committee at IARC (International Agency for Research on Cancer), France.

\section{Data analysis}

The association between maternal HBV markers (HBsAg, HBeAg) and e antigenaemia was examined in successive generations: mothers of index women $\left(1^{\text {st }}\right.$ generation $)$ and index women ( $2^{\text {nd }}$ generation); and index women $\left(2^{\text {nd }}\right.$ generation) and their children ( ${ }^{\text {rd }}$ generation). The effect of the number of older siblings positive for $\mathrm{HBsAg}$ or $\mathrm{HBeAg}$ was evaluated in index women ( $2^{\text {nd }}$ generation) and their children ( $3^{\text {rd }}$ generation).

Logistic regression was used to estimate adjusted odds ratios for the associations between familial HBV serostatus (maternal sero-status and number of elder siblings positive for $\mathrm{HBV}$ markers) and e antigenaemia in index women $\left(2^{\text {nd }}\right.$ generation). In the children of index women ( $3^{\text {rd }}$ generation), adjusted odds ratios for the same associations were estimated using generalised estimating equations with an exchangeable correlation structure to account for household clustering (the previous analysis 


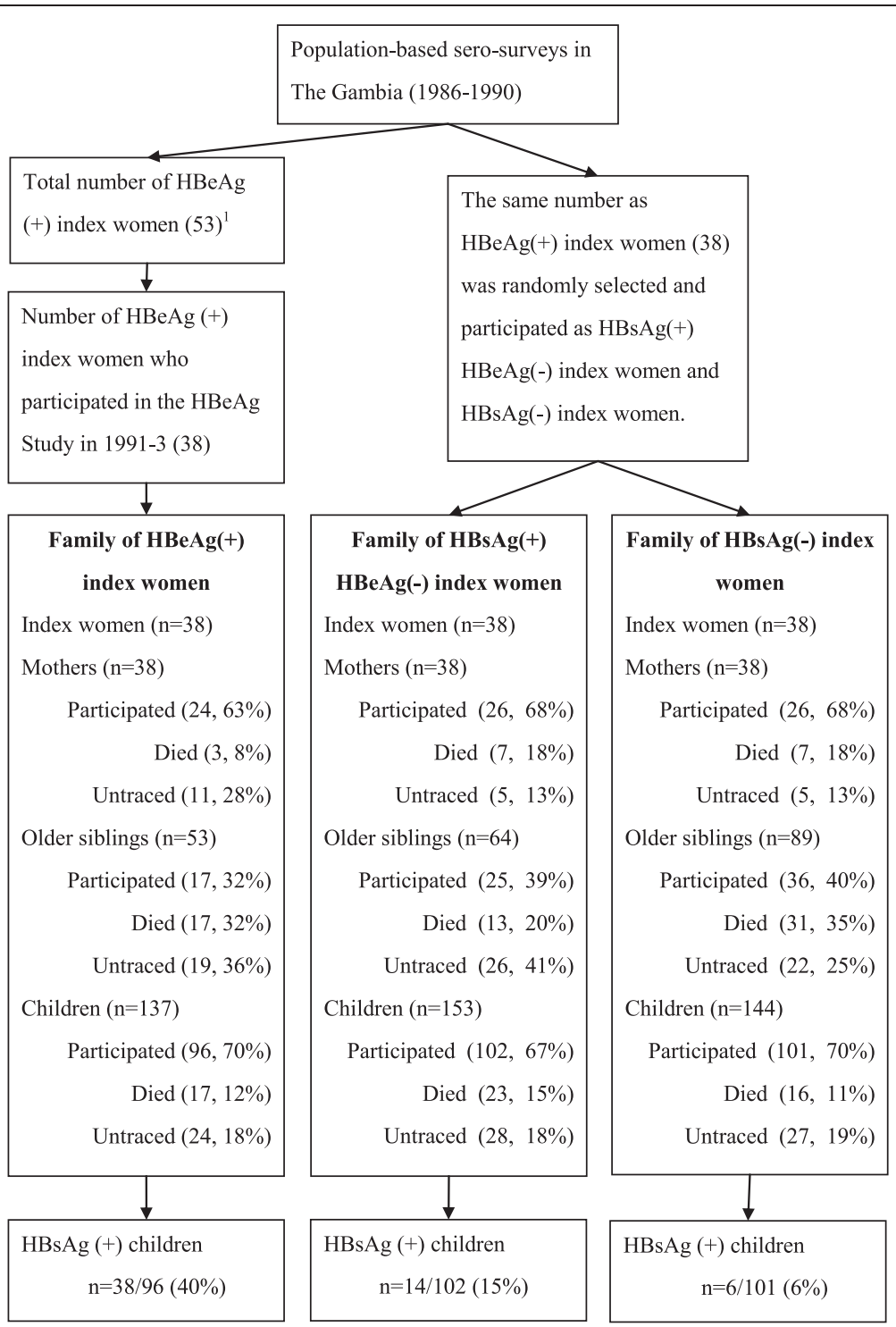

Figure 1 Flow chart of study participants in the HBeAg Study, The Gambia, 1991-1993. 'Origins of HBeAg-positive mothers are the following: GHIS group $1(n=18)$, GHIS group $3(n=17)$, Arthropod study $(n=6)$, Manduar sero-survey $(n=4)$, Farafenni sero-survey $(n=6)$, and Banjul sero-survey $(n=2)$.

did not account for household clustering because none of index women shared the same mother). A linear test for trend was used to assess the statistical significance of the number of elder siblings positive for $\mathrm{HBeAg}$ and the number positive for HBsAg.

A minimally sufficient set of a priori confounders of the association between each of the familial sero-markers and e antigenaemia was identified from a causal diagram (Figure 2) by applying the backdoor test [12]. The set of confounders was the same for each familial sero-marker, and consisted of: year of birth, total sibship size (as a proxy for parental socioeconomic status), and the other familial HBV sero-status measures. To estimate the effect of maternal HBeAg, the set of confounders was: year of birth, total sibship size, maternal HBsAg, number of older siblings with positive $\mathrm{HBsAg}$, and number of older siblings with positive $\mathrm{HBeAg}$. And to estimate the effect of the number of older siblings with positive $\mathrm{HBeAg}$, the set of confounders was: year of birth, total sibship size, maternal HBsAg, maternal HBeAg, and number of older siblings with positive HBsAg. A history of hepatitis B vaccination in children of index women was not considered a confounder for the association of maternal HBV sero-status with e antigenaemia in children, because hepatitis $B$ vaccine was given irrespective of maternal HBV sero-status $[10,13]$. The mothers of index women $\left(1^{\text {st }}\right.$ generation) were all negative for $\mathrm{HBeAg}$ and only one index woman had an HBeAg-positive older sibling. These variables 


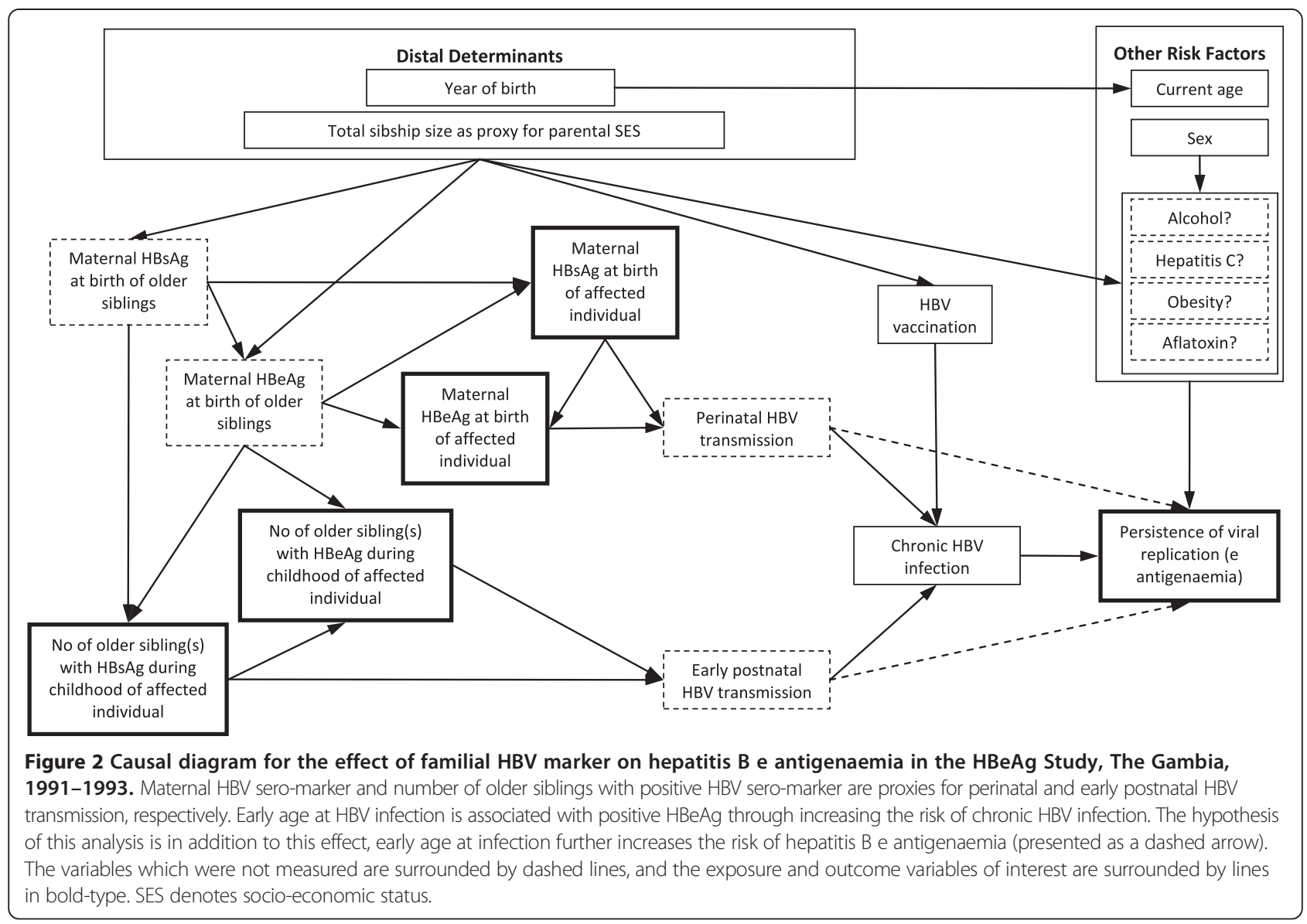

were therefore omitted from multivariable models of eantigenaemia in index women ( $2^{\text {nd }}$ generation).

\section{Results}

\section{Participation}

Out of $53 \mathrm{HBeAg}$-positive index women ( $2^{\text {nd }}$ generation) in the database, 38 (71.7\%) were traced and agreed to participate in the study. The rate of refusal among HBeAg-negative index women was not recorded. More than $65 \%$ of the mothers $\left(1^{\text {st }}\right.$ generation $)$ and children $\left(3^{\text {rd }}\right.$ generation) of index women participated in the study, but participation was less than $35 \%$ among older siblings of index women (Figure 1).

\section{Index women $\left(2^{\text {nd }}\right.$ generation)}

The characteristics of $38 \mathrm{HBsAg}$-positive HBeAg-positive index women and $38 \mathrm{HBsAg}$-positive HBeAg-negative index women are presented in Table 1 . The median age in index women was 25.0 years (interquartile range: 23-30) for HBeAg-positive and 26.5 years (interquartile range: 22-30) for HBeAg-negative index women (Wilcoxon rank-sum test: $\mathrm{p}=0.75$ ). The associations between familial $\mathrm{HBV}$ sero-status and $\mathrm{HBeAg}$ positivity in $\mathrm{HBsAg}$-positive index women are presented in Table 2. The proportion of index women who have HBsAg-positive mothers was higher in HBeAg-positive index women $(16.7 \%, 4 / 24)$ than in HBsAg-positive HBeAg-negative index women $(7.7 \%, 2 / 26)$, although the difference was not statistically significant $(\mathrm{p}=0.33)$. None of the HBsAg-positive mothers of index women $\left(1^{\text {st }}\right.$ generation) were HBeAg-positive. The proportion of index women with HBsAg-positive older siblings was similar in HBeAg-positive index women (15.4\%, 4/26) and HBsAg-positive HBeAg-negative index women $(17.2 \%, 5 / 29)$. After adjusting for confounding factors, there was no evidence for an association between HBeAg positivity in index women and either maternal $\mathrm{HBsAg}$ (OR 1.2, 95\% CI: 0.1-23.2, $\mathrm{p}=0.89$ ) or having an HBsAgpositive older sibling (OR 0.9, 95\% CI: 0.2-5.5, $\mathrm{p}=0.92$ ).

\section{Children of index women ( $3^{\text {rd }}$ generation)}

In total, 96, 102 and 101 children of HBeAg-positive, HBsAg-positive and HBeAg-negative, and HBsAg-negative index women participated, respectively. Of whom, 38 (39.6\%), 14 (13.7\%) and 6 (5.9\%) tested positive for HBsAg, respectively $(\mathrm{p}<0.001$, Figure 1$)$. The characteristics of these HBsAg-positive children $(n=58)$ by maternal HBV marker are presented in Table 3. The median age was similar in the three groups. However, HBsAg-positive 
Table 1 Characteristics of HBsAg-positive HBeAg-positive index women and HBsAg-positive HBeAg-negative index women ( $2^{\text {nd }}$ generation)

\begin{tabular}{|c|c|c|c|c|c|}
\hline \multirow[t]{2}{*}{ Variables } & & \multicolumn{2}{|c|}{ HBsAg (+) HBeAg (+) index women $(n=38)$} & \multicolumn{2}{|c|}{ HBsAg (+) HBeAg (-) index women $(n=38)$} \\
\hline & & No & $\%$ & No & $\%$ \\
\hline \multirow[t]{3}{*}{ Age group } & $17-20$ & 6 & 15.8 & 7 & 18.4 \\
\hline & $21-30$ & 25 & 65.8 & 22 & 57.9 \\
\hline & $31-45$ & 7 & 18.4 & 9 & 23.7 \\
\hline \multirow[t]{3}{*}{ Year of birth } & 1948-1960 & 6 & 15.8 & 8 & 21.0 \\
\hline & 1961-1970 & 27 & 71.0 & 24 & 63.2 \\
\hline & 1971-1974 & 5 & 13.2 & 6 & 15.8 \\
\hline \multirow[t]{3}{*}{ Total sibship size } & $1-4$ & 16 & 42.1 & 8 & 21.0 \\
\hline & $5-6$ & 12 & 31.6 & 15 & 39.5 \\
\hline & $\geq 7$ & 10 & 26.3 & 15 & 39.5 \\
\hline
\end{tabular}

children with HBeAg-positive mothers were more likely to be female, HBV vaccinated and to have three or fewer siblings than HBsAg-positive children born to HBeAg-negative mothers.

The associations between familial HBV sero-status and $\mathrm{HBeAg}$ positivity in HBsAg-positive children $\left(3^{\text {rd }}\right.$ generation) are presented in Table 4 . There was a non-significant trend that $\mathrm{HBeAg}$ prevalence in children increased with increasing number of HBeAg-positive older siblings (64.1\%, $69.2 \%$ and $83.3 \%$ in children with 0,1 , and $\geq 2 \mathrm{HBeAg}$ positive older siblings, respectively), but there was no trend after adjusting for confounding. In contrast, the presence of maternal $\mathrm{HBeAg}$ was a risk factor for $\mathrm{HBeAg}$ positivity after adjusting for confounding (adjusted OR 4.5, 95\% CI: $1.0-19.5, \mathrm{p}=0.04)$. The prevalence of e antigenaemia was similar between vaccinated $(70.0 \%, 7 / 10)$ and unvaccinated (66.7\%, 32/48, $\mathrm{p}=0.84)$ children.

\section{Discussion}

We examined the effect of HBV sero-markers in mothers and older siblings on hepatitis B e antigenaemia in children carrying HBsAg ( ${ }^{\text {rd }}$ generation). We found that $\mathrm{e}$ antigenaemia in children was positively associated with maternal $\mathrm{HBeAg}$ but not with maternal HBsAg. Likewise, the prevalence of e antigenaemia in children was higher if older siblings were $\mathrm{HBeAg}$ positive, although this result was not statistically significant. These relationships imply that the early establishment of chronic HBV infection through perinatal transmission from infectious mothers, as well as early postnatal transmission from infectious older siblings is associated with presence of $\mathrm{HBeAg}$. In addition, this is consistent with the observation that positive HBeAg confers greater infectivity than HBsAg positivity alone. For example, the risk of perinatal transmission is $10-17 \%$ in $\mathrm{HBsAg}$-positive mothers

Table 2 Risk factors for HBeAg positivity in HBsAg-positive index women ( ${ }^{\text {nd }}$ generation)

\begin{tabular}{|c|c|c|c|c|c|c|c|c|c|c|}
\hline \multirow[t]{2}{*}{ Variables } & \multicolumn{2}{|c|}{$\begin{array}{l}\text { HBsAg (+) HBeAg }(+) \\
\text { index women }(n=38)\end{array}$} & \multicolumn{2}{|c|}{$\begin{array}{l}\text { HBsAg (+) HBeAg (-) } \\
\text { index women }(n=38)\end{array}$} & \multicolumn{3}{|c|}{ Crude odds ratios } & \multicolumn{3}{|c|}{ Adjusted odds ratios ${ }^{1}$} \\
\hline & No & $\%$ & $\overline{\text { No }}$ & $\%$ & OR & $95 \% \mathrm{Cl}$ & $\mathbf{P}$ & OR & $95 \% \mathrm{Cl}$ & $\mathbf{P}$ \\
\hline \multicolumn{11}{|c|}{ Maternal HBsAg (1 ${ }^{\text {st }}$ generation) } \\
\hline Negative & 20 & 83.3 & 24 & 92.3 & 1.0 & & 0.3 & 1.0 & & 0.9 \\
\hline Positive & 4 & 16.7 & 2 & 7.7 & 2.4 & $0.4-14.5$ & & 1.2 & $0.1-23.2$ & \\
\hline \multicolumn{11}{|c|}{ Maternal HBeAg ( $1^{\text {st }}$ generation) } \\
\hline Negative & 24 & 100 & 26 & 100 & 1.0 & & & 1.0 & & \\
\hline Positive & 0 & 0 & 0 & 0 & $\mathrm{~N} / \mathrm{A}$ & & & $\mathrm{N} / \mathrm{A}$ & & \\
\hline \multicolumn{11}{|c|}{ No. of older siblings with positive HBsAg } \\
\hline 0 & 22 & 84.6 & 24 & 82.8 & 1.0 & & 0.9 & 1.0 & & 0.9 \\
\hline $1-2$ & 4 & 15.4 & 5 & 17.2 & 0.9 & $0.2-3.7$ & & 0.9 & $0.2-5.5$ & \\
\hline \multicolumn{11}{|c|}{ No. of older siblings with positive $\mathrm{HBeAg}$} \\
\hline 0 & 25 & 96.2 & 29 & 100 & 1.0 & & & 1.0 & & \\
\hline 1 & 1 & 3.8 & 0 & 0 & $\mathrm{~N} / \mathrm{A}$ & & & $\mathrm{N} / \mathrm{A}$ & & \\
\hline
\end{tabular}

${ }^{1}$ Model included maternal HBsAg, number of older siblings with $\mathrm{HBsAg}$, year of birth, and total sibship size. 
Table 3 Characteristics of HBsAg-positive children ( $3^{\text {rd }}$ generation) according to maternal HBV sero-status

\begin{tabular}{|c|c|c|c|c|c|c|c|}
\hline \multirow[t]{2}{*}{ Variables } & & \multicolumn{2}{|c|}{ HBsAg(+) HBeAg(+) mother $(n=38)$} & \multicolumn{2}{|c|}{ HBsAg(+) HBeAg(-) mother $(n=14)$} & \multicolumn{2}{|c|}{ HBsAg(-) mother $(n=6)$} \\
\hline & & No. & $\%$ & No. & $\%$ & No. & $\%$ \\
\hline \multirow[t]{2}{*}{ Sex } & Male & 12 & 31.6 & 8 & 57.1 & 5 & 83.3 \\
\hline & Female & 26 & 68.4 & 6 & 42.9 & 1 & 16.7 \\
\hline \multirow[t]{3}{*}{ Age group } & $0-5$ & 15 & 39.5 & 2 & 14.3 & 3 & 50.0 \\
\hline & $6-10$ & 16 & 42.1 & 9 & 64.3 & 2 & 33.3 \\
\hline & $\geq 11$ & 7 & 18.4 & 3 & 21.4 & 1 & 16.7 \\
\hline \multirow[t]{3}{*}{ Year of birth } & 1973-1980 & 5 & 13.2 & 3 & 21.4 & 1 & 16.7 \\
\hline & 1981-1985 & 18 & 47.4 & 9 & 64.3 & 3 & 50.0 \\
\hline & 1986-1991 & 15 & 39.4 & 2 & 14.3 & 2 & 33.3 \\
\hline \multirow[t]{3}{*}{ Total sibship size } & $1-3$ & 10 & 26.3 & 1 & 7.1 & 1 & 16.7 \\
\hline & $4-5$ & 9 & 23.7 & 7 & 50.0 & 5 & 83.3 \\
\hline & $6-7$ & 19 & 50.0 & 6 & 42.9 & 0 & 0.0 \\
\hline \multirow[t]{2}{*}{ HBV vaccination } & No & 28 & 73.7 & 14 & 100 & 6 & 100 \\
\hline & Yes & 10 & 26.3 & 0 & 0.0 & 0 & 0.0 \\
\hline
\end{tabular}

without $\mathrm{HBeAg}$ and $63-67 \%$ in $\mathrm{HBeAg}$ positive mothers in sSA [14,15]. Indeed, in the current study, we observed that prevalence of $\mathrm{HBsAg}$ in children with $\mathrm{HBeAg}$-positive mothers was significantly higher than that in children with HBsAg-positive but HBeAg-negative mothers (40\% versus $15 \%$ ).

The associations of familial HBeAg with e antigenaemia in index women ( $2^{\text {nd }}$ generation) could not be confirmed because all of the mothers of index women ( $1^{\text {st }}$ generation) tested negative for $\mathrm{HBeAg}$ and only one older sibling of index women tested positive for HBeAg. The low prevalence of $\mathrm{HBeAg}$ in the mothers and older siblings of index women was expected since $\mathrm{HBeAg}$ is lost over time. In The Gambia, $85 \%$ of children who established chronic HBV infection during early childhood had lost HBeAg by the second decade of life [16]. This makes it difficult to investigate the effect of familial HBeAg status in adults.

A strength of our study was that we could assess the effect of familial HBV sero-status, rather than a family history of HBV infection. The latter is inaccurate because the absence of such a history does not necessarily indicate that the family member was sero-negative for HBsAg [6].

Table 4 Risk factors for HBeAg positivity in HBsAg-positive children ( $3^{\text {rd }}$ generation)

\begin{tabular}{|c|c|c|c|c|c|c|c|}
\hline \multirow[t]{2}{*}{ Variables } & \multirow{2}{*}{$\begin{array}{l}\text { Prevalence } \\
\text { of } \mathrm{HBeAg}(+)\end{array}$} & \multicolumn{3}{|c|}{ Crude odds ratios } & \multicolumn{3}{|c|}{ Adjusted odds ratios ${ }^{2,3}$} \\
\hline & & OR & $95 \% \mathrm{Cl}$ & $\mathbf{P}$ & OR & $95 \% \mathrm{Cl}$ & $\mathbf{P}$ \\
\hline \multicolumn{8}{|c|}{ Maternal HBsAg (2 ${ }^{\text {nd }}$ generation) } \\
\hline Negative & $83.3 \%(5 / 6)$ & 1.0 & & 0.5 & 1.0 & & 0.5 \\
\hline Positive & $65.4 \%(34 / 52)$ & 0.4 & $0.1-4.2$ & & 0.4 & $0.1-5.3$ & \\
\hline \multicolumn{8}{|c|}{ Maternal HBeAg (2 ${ }^{\text {nd }}$ generation) } \\
\hline Negative & $60.0 \%(12 / 20)$ & 1.0 & & 0.5 & 1.0 & & 0.04 \\
\hline Positive & $71.1 \%(27 / 38)$ & 1.6 & $0.4-6.1$ & & 4.5 & $1.0-19.5$ & \\
\hline \multicolumn{8}{|c|}{ No of older siblings with positive HBsAg } \\
\hline 0 & $65.6 \%(21 / 32)$ & 1.0 & & $0.7^{1}$ & 1.0 & & $0.9^{1}$ \\
\hline 1 & $66.7 \%(10 / 15)$ & 1.0 & $0.3-3.8$ & & 1.1 & $0.2-7.2$ & \\
\hline$\geq 2$ & $72.7 \%(8 / 11)$ & 1.4 & $0.3-6.4$ & & 1.2 & $0.0-47.5$ & \\
\hline \multicolumn{8}{|c|}{ No. of older siblings with positive $\mathrm{HBeAg}$} \\
\hline 0 & $64.1 \%(25 / 39)$ & 1.0 & & $0.4^{1}$ & 1.0 & & $0.8^{1}$ \\
\hline 1 & $69.2 \%(9 / 13)$ & 1.3 & $0.3-4.9$ & & 1.1 & $0.3-4.9$ & \\
\hline$\geq 2$ & $83.3 \%(5 / 6)$ & 2.8 & $0.3-27.7$ & & 2.0 & $0.1-42.7$ & \\
\hline
\end{tabular}

${ }^{1}$ Linear test for trend.

${ }^{2}$ Model included maternal HBsAg, maternal HBeAg, number of older siblings with HBsAg, number of older siblings with $\mathrm{HBeAg}$, year of birth, and total sibship size.

${ }^{3}$ Wald test from generalised estimating equations. 
Second, we could control for the HBV markers of older siblings when assessing the association of maternal HBV sero-status with HBeAg positivity. And similarly the association between siblings' sero-status and $\mathrm{HBeAg}$ positivity was adjusted for maternal HBV markers. In other studies this has not been possible [4,17-22]. The mutual adjustment with siblings' sero-markers was particularly relevant in The Gambia, where sibling-to-sibling transmission during early childhood is the most frequent route $[8,9]$. After adjustment the OR for the association between maternal $\mathrm{HBeAg}$ and e antigenaemia in children increased whilst the ORs for the number of HBeAg-positive older siblings decreased. This suggests that perinatal maternal transmission might be more important in determining the risk of persistent viral replication than early horizontal transmission from older siblings in The Gambia. This is consistent with the hypothesis that earlier age at HBV infection is associated with higher risk of e antigenaemia.

Two African case-control studies have investigated the association between age at HBV infection and HCC, ultimate sequelae of chronic HBV infection. Larouze et al., found that the prevalence of maternal $\mathrm{HBsAg}$ was higher in HCC cases $(71.4 \%, 20 / 28)$ than in healthy controls $(14.3 \%, 4 / 28, \mathrm{P}<0.0001)$ while the prevalence of HBsAg in siblings was similar in cases $(9.6 \%, 7 / 73)$ and controls $(14 \%, 8 / 58)$ [3]. Ryder et al., studied the association between birth order and HCC, and found strong evidence that higher birth order, and hence earlier age at infection, is associated with higher HCC risk $(\mathrm{P}<0.005)$ [23]. In the absence of immunisation, children with low birth order are exposed to HBV after they start schooling, whilst children with high birth order are infected much earlier by their older siblings who got the infection outside the household [24]. However, because individuals negative for $\mathrm{HBsAg}$ were included in both studies, the associations might be due to an increased risk of chronic HBV infection related with early age at infection. The results of these studies are therefore not directly comparable to our findings.

The study has several limitations. Firstly, the sample size was small, and the associations were therefore poorly estimated. Secondly, many family members of the index women did not participate in the HBeAg study, and this might have led to selection bias. Thirdly, important confounding variables might have been omitted, in particular viral genotype. In Taiwan where genotype B (80\%) and $C(20 \%)$ predominate, genotype $C$ was found to be associated with delayed HBeAg seroconversion [25] and also with more frequent mother-to-infant transmission [4]. In The Gambia, genotype $\mathrm{E}$ is predominant (75-95\%) followed by A [26-28]. Although there are only few African studies relating viral genotypes to clinical outcomes [29], preliminary data from other West African countries (Nigeria, Cameroon and Mali) suggest that $\mathrm{HBeAg}$ prevalence might be higher in subjects infected with genotype $\mathrm{E}(89.8 \%, 35 / 39)$ than in those with genotype A $(33.3 \%, 2 / 6)[30]$.

HBV vaccination programmes in Africa and Asia have been successful in preventing postnatal horizontal transmission of $\mathrm{HBV}$, thereby reducing the prevalence of chronic HBV infection [31,32]. However, they have had a limited impact on perinatal mother-to-infant transmission, especially when the mothers are $\mathrm{HBeAg}$-positive or highly viraemic [31,33]. In East Asia, where perinatal maternal transmission is common, HBV vaccine is frequently given within 24 hours of delivery (i.e. timely birth dose) $[34,35]$. By contrast a timely birth dose of HBV vaccine is rarely administered in Africa because logistical challenges seem to outweigh its potential impact due to the relatively low frequency of mother-to-infant transmission [36]. Despite a high coverage of hepatitis B vaccine, only six countries in SSA are undertaking the birth dose by the end of 2012 and The Gambia is one of them [37]. However, in two villages in rural Gambia where HBV vaccine efficacy was evaluated [31], only $2.8 \%(63 / 2173)$ of children who were vaccinated against HBV between 1984 and 2007 were given a dose within 24 hours of birth (unpublished data). This might be because in The Gambia, most children are born at home, and are usually not taken away from home in the first week [38].

\section{Conclusion}

Our study suggests that the risk of prolonged e antigenaemia, an important predictor of HCC [39], is higher in individuals who perinatally established chronic infection through infectious mothers than in those infected with HBV by horizontal transmission. This implies that interrupting mother-to-infant transmission in sub-Saharan Africa might help reduce the burden of liver disease. A timely dose of $\mathrm{HBV}$ vaccine within 24 hours of birth, as recommended by WHO [40], needs to be implemented in sub-Saharan Africa.

\section{Abbreviations \\ HBeAg: Hepatitis B e antigen; HBsAg: Hepatitis B surface antigen; HBV: Hepatitis B virus; HCC: Hepatocellular carcinoma; IARC: International agency for research on cancer; MRC: Medical research council; OR: Odds ratio; sSA: Sub-Saharan Africa; WHO: World health organisation.}

\section{Competing interests}

The authors declare that they have no competing interests.

\section{Authors' contributions}

MM conducted the surveys, performed laboratory tests and helped to improve the manuscript. YS designed the analysis of the study, performed the statistical analysis and drafted the manuscript. CB supervised the statistical analysis and helped to improve the manuscript. RN supported the conduct of the study. All authors read and approved the final manuscript.

\section{Acknowledgements}

The authors would thank the Gambia Government, WHO/IARC and MRC which supported the study. We also thank Prof Andrew Hall, Prof Hilton Whittle and Dr Abdoulie Jack who initiated the study. Finally, we acknowledge all the study participants in this study. 


\section{Author details}

${ }^{1}$ Medical Research Council (MRC) Unit, Atlantic Boulevard, Fajara, P.O. Box 273, Banjul, The Gambia. ${ }^{2}$ Department of Infectious Disease Epidemiology, London School of Hygiene and Tropical Medicine, Keppel Street, London WC1E 7HT, UK. ${ }^{3}$ The Gambia Hepatitis Intervention Study, IARC, c/o MRC Unit, Atlantic Boulevard, Fajara, P.O. Box 273, Banjul, West Africa, The Gambia. ${ }^{4}$ International Agency for Research on Cancer (IARC), 150 Cours Albert Thomas, Lyon CEDEX 08 69372, France.

\section{Received: 3 March 2014 Accepted: 23 May 2014}

Published: 30 May 2014

\section{References}

1. IARC Working Group on the Evaluation of Carcinogenic Risks to Humans: IARC Monographs on the Evaluation of Carcinogenic Risks to Humans. Volume 100. A Review of Human Carcinogens. Part B. Biological Agents. Lyon, France: International Agency for Research on Cancer; 2011:1-487.

2. Edmunds WJ, Medley GF, Nokes DJ, Hall AJ, Whittle HC: The influence of age on the development of the hepatitis B carrier state. Proc Biol Sci 1993, 253:197-201.

3. Larouze B, Saimot G, Lustbader ED, London WT, Werner BG, Payet M: Host responses to hepatitis-B infection in patients with primary hepatic carcinoma and their families. A case/control study in Senegal, West Africa. Lancet 1976, 2:534-538.

4. Tseng YR, Wu JF, Ni YH, Chen HL, Chen CC, Wen WH, Hsu HY, Chang MH: Long-term effect of maternal HBeAg on delayed HBeAg seroconversion in offspring with chronic hepatitis B infection. Liver Int 2011, 31:1373-1380.

5. Hadziyannis SJ: Natural history of chronic hepatitis B in EuroMediterranean and African countries. J Hepatol 2011, 55:183-191.

6. Shimakawa Y, Yan H-J, Tsuchiya N, Bottomley C, Hall AJ: Association of early age at establishment of chronic hepatitis B infection with persistent viral replication, liver cirrhosis and hepatocellular carcinoma: a systematic review. PLoS One 2013, 8:e69430.

7. Edmunds WJ, Medley GF, Nokes DJ, O'Callaghan CJ, Whittle HC, Hall AJ: Epidemiological patterns of hepatitis B virus (HBV) in highly endemic areas. Epidemiol Infect 1996, 117:313-325.

8. Whittle HC, Bradley AK, McLauchlan K: Hepatitis B virus infection in two Gambian villages. Lancet 1983, 1:1203-1206.

9. Whittle H, Inskip H, Bradley AK, McLaughlan K, Shenton F, Lamb W, Eccles J, Baker BA, Hall AJ: The Pattern of Childhood Hepatitis B Infection in Two Gambian Villages. J Infect Dis 1990, 161:1112-1115.

10. The Gambia Hepatitis Study Group: The Gambia hepatitis intervention study. Cancer Res 1987, 47:5782-5787.

11. Vall Mayans M, Hall A, Inskip H, Chotard J, Lindsay S, Alonso P, Coromina E, Mendy M, Whittle H: Risk factors for transmission of hepatitis B virus to Gambian children. Lancet 1990, 336:1107-1109.

12. Greenland S, Pearl J, Robins JM: Causal diagrams for epidemiologic research. Epidemio/ 1999, 10:37-48.

13. Whittle HC, Inskip H, Hall AJ, Mendy M, Downes R, Hoare S: Vaccination against hepatitis $B$ and protection against chronic viral carriage in The Gambia. Lancet 1991, 337:747-750.

14. Barin F, Perrin J, Chotard J, Denis F, N'Doye R, Diop Mar I, Chiron JP, Coursaget P, Goudeau A, Maupas P: Cross-sectional and longitudinal epidemiology of hepatitis B in Senegal. Prog Med Virol 1981, 27:148-162

15. Botha JF, Dusheiko GM, Ritchie MJJ, Mouton HWK, Kew MC: Hepatitis B virus carrier state in Black children in Ovamboland: Role of perinatal and horizontal infection. Lancet 1984, 323:1210-1212.

16. Mendy ME, McConkey SJ, van der Sande MAB, Crozier $S$, Kaye $S$, Jeffries $D$, Hall AJ, Whittle HC: Changes in viral load and HBsAg and HBeAg status with age in HBV chronic carriers in The Gambia. Virol J 2008, 5:49.

17. Beasley RP: Hepatitis B virus as the etiologic agent in hepatocellular carcinoma - epidemiologic considerations. Hepatology 1982, 2(suppl):21S-26S.

18. Kojima M, Yasuda M, Tanaka H, Adachi N, MS: Natural seroconversion of HBe antigen to anti-HBe in $\mathrm{HBs}$ antigen carrier children-From the difference of the modes of HBV transmission [Japanese]. Acta Hepatol Jpn 1985, 26:1139-1145

19. Chang MH, Sung JL, Lee CY, Chen CJ, Chen JS, Hsu HY, Lee PI, Chen DS: Factors affecting clearance of hepatitis B e antigen in hepatitis B surface antigen carrier children. J Pediatr 1989, 115:385-390

20. Wheeley SM, Tarlow MJ, Boxall EH: Chronic hepatitis B in male and female children of HBsAg carrier mothers. J Hepatol 1989, 8:226-231.
21. Hopkirk N, Moyes CD, Lucas CR: Liver function and hepatitis markers in carriers of hepatitis B virus in New Zealand. N Z Med J 2000, 113:114-116.

22. Soderstrom A, Norkrans G, Conradi N, Krantz M, Horal P, Lindh M: Histologic activity of childhood chronic hepatitis B related to viremia levels, genotypes, mutations, and epidemiologic factors. J Pediatr Gastroenterol Nutr 2002, 35:487-494.

23. Ryder RW, Whittle HC, Sanneh AB, Ajdukiewicz AB, Tulloch S, Yvonnet B: Persistent hepatitis $B$ virus infection and hepatoma in The Gambia, west Africa. A case-control study of 140 adults and their 603 family contacts. Am J Epidemiol 1992, 136:1122-1131.

24. Hsieh CC, Tzonou A, Zavitsanos X, Kaklamani E, Lan SJ, Trichopoulos D: Age at first establishment of chronic hepatitis B virus infection and hepatocellular carcinoma risk: A birth order study. Am J Epidemiol 1992, 136:1115-1121.

25. Chu C, Hussain M, Lok ASF: Hepatitis B virus genotype B is associated with earlier $\mathrm{HBeAg}$ seroconversion compared with hepatitis $B$ virus genotype C. Gastroenterology 2002, 122:1756-1762.

26. Dumpis U, Mendy M, Hill A, Thursz M, Hall A, Whittle H, Karayiannis P: Prevalence of HBV core promoter/precore/core mutations in Gambian chronic carriers. J Med Virol 2001, 65:664-670.

27. Villar S, Le Roux-Goglin E, Gouas DA, Plymoth A, Ferro G, Boniol M, Lereau M, Bah E, Hall AJ, Wild CP, Mendy M, Norder H, van der Sande M, Whittle H, Friesen MD, Groopman JD, Hainaut P: Seasonal variation in TP53 R249Smutated serum DNA with aflatoxin exposure and hepatitis $B$ virus infection. Environ Health Perspect 2011, 119:1635-1640.

28. Gouas DA, Villar S, Ortiz-Cuaran S, Legros P, Ferro G, Kirk GD, Lesi OA, Mendy M, Bah E, Friesen MD, Groopman J, Chemin I, Hainaut P: TP53 R249S mutation, genetic variations in HBX and risk of hepatocellular carcinoma in The Gambia. Carcinogenesis 2012, 33:1219-1224.

29. Kramvis A, Kew MC: Epidemiology of hepatitis B virus in Africa, its genotypes and clinical associations of genotypes. Hepatol Res 2007, 37:S9-S19.

30. Olinger CM, Venard V, Njayou M, Oyefolu AOB, Maïga I, Kemp AJ, Omilabu SA le Faou A, Muller CP: Phylogenetic analysis of the precore/core gene of hepatitis $B$ virus genotypes $E$ and $A$ in West Africa: new subtypes, mixed infections and recombinations. J Gen Virol 2006, 87:1163-1173.

31. Mendy M, Peterson I, Hossin S, Peto T, Jobarteh ML, Jeng-Barry A, Sidibeh M, Jatta A, Moore SE, Hall AJ, Whittle H: Observational study of vaccine efficacy 24 years after the start of hepatitis B vaccination in two Gambian villages: no need for a booster dose. PLoS One 2013, 8:e58029.

32. Ni Y-H, Chang M-H, Wu J-F, Hsu H-Y, Chen H-L, Chen D-S: Minimization of hepatitis B infection by a 25 -year universal vaccination program. J Hepatol 2012, 57:730-735.

33. Chen H-L, Lin L-H, Hu F-C, Lee J-T, Lin W-T, Yang Y-J, Huang F-C, Wu S-F, Chen SC-C, Wen W-H, Chu C-H, Ni Y-H, Hsu H-Y, Tsai P-L, Chiang C-L, Shyu M-K, Lee P-I, Chang F-Y, Chang M-H: Effects of maternal screening and universal immunization to prevent mother-to-infant transmission of HBV. Gastroenterology 2012, 142:773-781. e2.

34. Chen D-S: Hepatitis B vaccination: The key towards elimination and eradication of hepatitis B. J Hepatol 2009, 50:805-816.

35. Cui F, Luo H, Wang F, Zheng H, Gong X, Chen Y, Wu Z, Miao N, Kane M, Hennessey K, Hadler SC, Hutin YJ, Liang X, Yang W: Evaluation of policies and practices to prevent mother to child transmission of hepatitis $B$ virus in China: Results from China GAVI project final evaluation. Vaccine 2013, 31(Suppl 9):J36-J42

36. Kramvis A, Clements CJ: Implementing a birth dose of hepatitis B vaccine for home deliveries in Africa-Too soon? Vaccine 2010, 28:6408-6410.

37. WHO: Global routine vaccination coverage, 2012. Wkly Epidemiol Rec 2013, 88:482-486

38. The Gambia Hepatitis Study Group: Hepatitis B vaccine in the Expanded Programme of Immunisation: the Gambian experience. Lancet 1989, 1:1057-1060.

39. Yang HI, Lu SN, Liaw YF, You SL, Sun CA, Wang LY, Hsiao CK, Chen PJ, Chen DS, Chen CJ: Hepatitis B e antigen and the risk of hepatocellular carcinoma. N Engl J Med 2002, 347:168-174.

40. WHO: Hepatitis B vaccines. WHO position paper. Wkly Epidemiol Rec 2009, $84: 405-420$

doi:10.1186/1471-2458-14-532

Cite this article as: Shimakawa et al:: The association between maternal hepatitis B e antigen status, as a proxy for perinatal transmission, and the risk of hepatitis B e antigenaemia in Gambian children. BMC Public Health 2014 14:532 